\title{
Assessing of Some Toxic Heavy Metals Levels and Using Geo Accumulation Index in Sediment of Shatt Al-Arab and the Iraqi Marine Region
}

\author{
Zuhair A. Abdulnabi ${ }^{1 *} \quad$ Muhand K. Altememi ${ }^{1} \quad$ Wesal F.Hassan $^{2}$ \\ Dounia K.KassafAl-Khuzaie ${ }^{2} \quad$ Salah M.Saleh ${ }^{1}$
}

Received 1/10/2018, Accepted16/1/2019, Published 2/6/2019

This work is licensed under a Creative Commons Attribution 4.0 International License.

\begin{abstract}
:
Mercury, arsenic, cadmium and lead, were measured in sediment samples of river and marine environmental of Basra governorate in southern of Iraq. Sixteen sites of sediment were selected and distributed along Shatt Al-Arab River and the Iraqi marine environment. The samples were distributed among one station on Euphrates River before its confluence with Tigris River and Shatt Al-Arab formation, seven stations along Shatt Al-Arab River and eight stations were selected from the Iraqi marine region. All samples were collected from surface sediment in low tide time. ICP technique was used for the determination of mercury and arsenic for all samples, while cadmium and lead were measured for the same samples by using Atomic Absorption Spectroscopy. The results for all the measurements in Shatt Al-Arab sediment showed the values at extent: $(0.0611-0.1233 \mu \mathrm{g} / \mathrm{g}),(0.5490-46.2052 \mu \mathrm{g} / \mathrm{g}),(2.3356-4.7773 \mu \mathrm{g} / \mathrm{g}),(51.3309$ $107.0358 \mu \mathrm{g} / \mathrm{g}$ ) for concentration of mercury, arsenic, cadmium and lead respectively. While the concentrations in marine sediment were recorded at range: arsenic $(0.3510-46.0110 \mu \mathrm{g} / \mathrm{g})$, cadmium $(3.5136-5.5905 \mu \mathrm{g} / \mathrm{g})$ and lead $(43.68974-75.37045 \mu \mathrm{g} / \mathrm{g})$. The statistical analysis for all stations was studied by using the software SPSS v-20.0. It shows there are no significant differences in the concentrations between stations at $\mathrm{P} \geq 0.05$ level and also the geo accumulation index was calculated for metals in all stations.
\end{abstract}

Keywords: Atomic Absorption Spectroscopy, ICP analysis, I-geo.

\section{Introduction:}

Sediments are considered as an important reservoir for various pollutants such as pesticides and heavy metals and also play an important role in the transfer of contaminants to aquatic system under the suitable conditions and also depend on interactions between water and sediment $(1,2)$. Heavy metals found in the earth's crust with varying ratios of metals and also some metals are essential in biological system such as Fe, Se, Zn, Mn...etc. They enter in human feed,animal and plant therefore the deficiencies or excess of essential metals concentration about allowable limit causes a lot of diseases for human and animal $(3,4)$. But some other elements has toxic properties such as $\mathrm{Hg}, \mathrm{As}, \mathrm{Cd}, \mathrm{Pb}$...etc. Arsenic is relatively a rare element in the earth crust and it's not found in pure state in nature.The concentration of arsenic for uncontaminated soils and sediment are commonly

${ }^{1}$ Department of Marine Chemistry, Marine Science Center, University of Basrah, Basrah, Iraq

${ }^{2}$ Department of Applied Marine Science, College of Marine Science, University of Basrah, Basrah, Iraq

*Corresponding author: zuhir38@yahoo.com below $0.25 \mu \mathrm{g} / \mathrm{g}$, but it may reach upto $3.0 \mu \mathrm{g} / \mathrm{g}$ depending on the soil origin material $(5,6)$. Arsenic has the four states of oxidation are arsine (-III), arsenic $(0)$, arsenite $(+\mathrm{III})$, arsenate $(+\mathrm{V})$, while the oxidation states of arsine and arsenic occur only rarely in nature. It can form both organic and inorganic compounds,arsenic exists in several common minerals such asarsenopyrite (FeAsS), orpiment $\left(\mathrm{As}_{2} \mathrm{~S}_{3}\right)$, realgar $\left(\mathrm{As}_{2} \mathrm{~S}_{2}\right)$. Arsenic in soil and sediment binds with ferric oxide in clay minerals and organic material. It is considered as a toxic elements for ecosystem and causes cancer disease for human and threshold of a toxicity is mostly determined by environmental pollution following: industrial, anthropogenic and agricultural activities. The sources of arsenic contamination in soils are often associated with metals as lead, copper and cadmium $(5,6,7)$.

Mercury exists naturally in the metallic form or its binds with sulfide ores such as cinnabar (mercury sulfide). Asmall concentration of mercury 
is found during the lithosphere, atmosphere, hydrosphere and the biosphere. The earth crust contains $0.5 \mu \mathrm{g} / \mathrm{g}$ while ambient air may contain $0.002-0.02 \mu \mathrm{g} / \mathrm{dm}^{3}$, and sea water contains about $0.03 \mathrm{mg} / 1$. Mercury is also found in trace amounts mainly in animal and plant tissues. Three states of oxidation known for mercury are 0 , I, II $(5,8)$. Mercury compounds were classified into three categories as follows: the volatile species such as $(\mathrm{Hg})$, reactive species such as mercury oxide and mercury complexes with (hydroxide, chloride, bromide, and organic acids) and non-reactive species such as methylmercury, $\mathrm{Hg}(\mathrm{CN})_{2}$ and mercury sulfide. Mercury cycles in the environment undergoes a change in the chemical forms. In the atmosphere mercury is moving in its volatile forms such as elemental vapor or methylmercury. In the marine and terrestrial environments the compound of inorganic mercury undergoes methylated that are converted to methylmercury species which are readily accumulated in marine organisms. The toxicity of mercury is known to be highly dependent on its chemical form therefore the organomercurycompounds is generally more toxic than inorganic mercury salts. Mercury has the ability to accumulate in the tissues of fish usually in the form of methylmercury, a highly toxic form. Moreover the increasing of mercury levels that causes many diseases for human as Minamata disease which causes mental disturbance, loss of balance, speech, sight and hearing difficulty in swallowing and degeneration of brain $(8,9,10)$.

Lead is also considered as a toxic element for ecosystem and it exists in the earth crust about $15 \mu \mathrm{g} / \mathrm{g}$. The average of the concentration of lead in the world soils can be range $2-200 \mu \mathrm{g} / \mathrm{g}$ and also the lead exists extensively in some rock such as the rock of argillaceous and magmatic at extent 10$40 \mu \mathrm{g} / \mathrm{g}$ while in the ultramafic rocks at range $0.1-$ $10 \mu \mathrm{g} / \mathrm{g}$ (11). Lead has been known to have toxic effects on human health because it has the ability of accumulation in bone and thus may cause cardiovascular, neurological, renal, gastrointestinal, hematologic and reproductive effects (12), and it has been used at most as a sensitive indicator of pollution. Lead can be volatile and it is released during high-temperature processes and also through the combustion of fuel that contains lead $(13,14)$. Cadmium is considered a rare element even though it is extensively distributed over the earth crust. Its estimated abundance in the earth crust is $0.1 \mu \mathrm{g} / \mathrm{g}$, but it does not exist as a free metal in nature (15). Cadmium exists widely in some rock such as sediment and volcanic rocks and estimated as follows: Ultramafic $0.12 \mu \mathrm{g} / \mathrm{g}$, Mafic $0.13-0.2 \mu \mathrm{g} / \mathrm{g}$, Granite 0.09-0.2 $\mu \mathrm{g} / \mathrm{g}$, Limestone 0.028-0.1 $\mu \mathrm{g} / \mathrm{g}$ and Sandstone $0.05 \mu \mathrm{g} / \mathrm{g}$ (16). Cadmium is a nonessential element but it's a toxic element for humans mainly affecting kidneys and the skeleton. It is also carcinogen by inhalation. Cadmium has the ability of accumulating in bone $(12,17)$ while in the environment, cadmium is toxic to plants, animals and micro-organisms (17). The most important sources of heavy metals pollution of ecosystem through natural and anthropogenic sources are weathering of rocks, combustion of coal and oil, mining, movement of wind, irrigation and drainage operations, wastewater and industrial waste. All these processes cause the ecosystem pollution of heavy metals $(16,17,18,19)$. We aim in current study to focused on evaluation of some toxic heavy metals level in Sediment samples because deficiency of studies about evaluation these metals in ecosystem in southern of Iraq and other hand its refer about pollution in aquatic system and thus cause different diseases for human, animals and plant.

\section{Material and Methods:}

Sediment samples were collected from river and marine environment in Basra governorate in the southern of Iraq. Sixteen stations were selected in Shatt Al-Arab River and the Iraqi marine regionas shown in Fig.1. The River sites represent various locations along Shatt Al-Arab River and divided into upstream $\left(Z_{1}-Z_{4}\right)$ and downstream $\left(Z_{5}-Z_{8}\right)$ and were distributed as follows: one station $\left(Z_{1}\right)$ on Euphrates River before its confluence with Tigris River and Shatt Al-Arab River formation. Seven stations $\left(Z_{2}-Z_{8}\right)$ were chosen on Shatt Al-Arab River from the north of Basra governorate to the south and these regions contain of many activities Such as population, agriculture, river navigation, industry (especially oil extraction industry) and commerce (3). Marine sites were selected and divided into Sea stations $\left(Z_{9}-Z_{11}\right)$ and Khor stations $\left(Z_{12}-Z_{16}\right)$ and were distributed as follows: three stations $\left(Z_{9}-Z_{11}\right)$ in southern of Fao city towards Khor Abdullah (these areas are important as they are the navigation road between Iraq and Kuwait) . Also five stations were chosen from Um Qasr region $Z_{12}$ towards Khor al Zubair region $Z_{15}$ and the last station $Z_{16}$ was selected from the nearby region from the confluence point with the Basra canal. The selected marine sites are important areas as they contain several activities such as industry, commerce and marine navigations because they contain oil and commercial ports. The marine samples were collected in winter season (December 2014) while Shatt Alarab River samples were collected in spring season (March 2015). All the samples were collected by grab sampler from 
surface sediment in low tide time and it was kept in plastic bags and preserved in cooling and then transferred to laboratory for carrying out different operations such as drying, grinding,digestion and analysis (20).

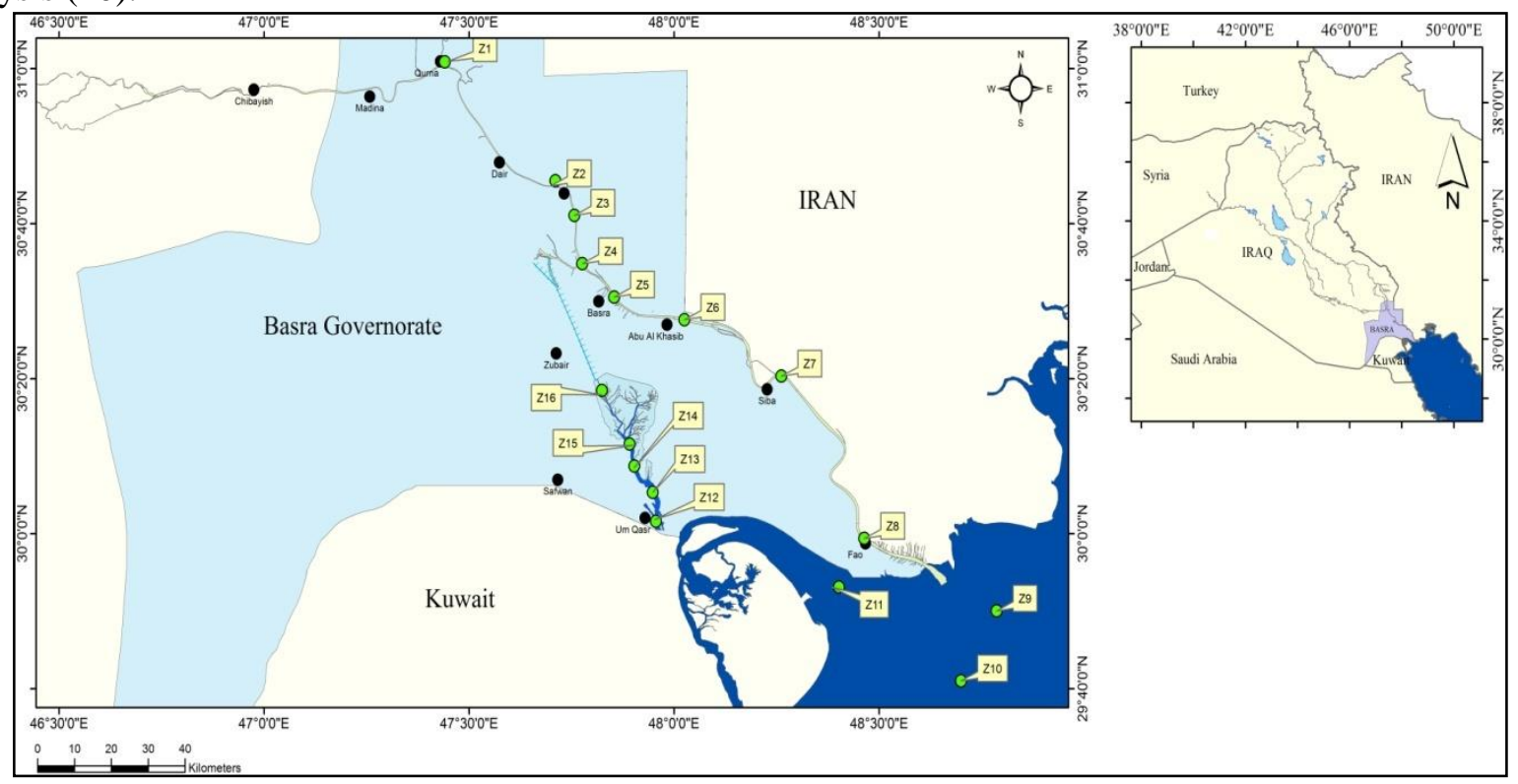

Figure 1. Locations of the sample selected in Southern of Iraq

Nitric acid (65\%), Sulfuric acid(97\%) and Hydrochloric acid (37\%) were obtained from Scharlau Company (Spain) . Per-chloric acid (70\%) and Hydrofluoric acid (40\%) were supplied by HimediaCompany (India). Deionized water was used for the preparation of all solutions for samples after the digestion operation.

Determination of four toxic elements in sediment samples was applied after digestion operation. Mercury and arsenic was measured by using ICP technique from type (ICP-OES HORIBA JY 2000-2) also the technique of Atomic Absorption Spectroscopy was used from type (Phoenix 986AA) for the measurement of cadmium and lead. Grab sampler was used for collecting all the samples from surface sediment. Hot plate instrument was used for digestion of all samples. The data were statistically analyzed by using the software SPSS v-20.0 by one way ANOVA to adopt the procedure of relative least significant difference (LSD) at the probability level $\mathrm{p} \geq 0.05$.

\section{Determination of geo accumulation index}

The geo accumulation index was calculated for different metals through using Muller equation (21) as follows:

$$
\text { I-geo }=\log _{2}(\mathrm{C} / 1.5 \mathrm{~B})
$$

Where: $\mathrm{C}$ is the measured value to the concentration of metals in the sediment, while $\mathrm{B}$ represents the background value to the concentration of metals in the sediment $(\mathrm{Hg}$ $0.5 \mu \mathrm{g} / \mathrm{g}$, As $0.25 \mu \mathrm{g} / \mathrm{g}, \mathrm{Cd} 0.1 \mu \mathrm{g} / \mathrm{g}$ and $\mathrm{Pb} 15 \mu \mathrm{g} / \mathrm{g}$ )
(22). The values of I-geo were classified according to Muller classification (23).

Table 1 . I-geo Classification

\begin{tabular}{|c|c|c|}
\hline $\begin{array}{l}\text { Type of } \\
\text { class }\end{array}$ & I-geo & Sediments pollution case \\
\hline Class 1 & $<0$ & $\begin{array}{l}\text { practically unpolluted- } \\
\text { Background sample }\end{array}$ \\
\hline Class 2 & $1-2$ & $\begin{array}{l}\text { unpolluted to moderately } \\
\text { polluted }\end{array}$ \\
\hline Class 3 & $2-3$ & moderately polluted to polluted \\
\hline Class 4 & $3-4$ & strongly polluted \\
\hline Class 5 & $4-5$ & strongly to extremely polluted \\
\hline Class 6 & $>5$ & extremely polluted \\
\hline
\end{tabular}

All the sediment samples were left to dry at room temperature after being collected from various regions of marine sediment and river sediment and they were kept in plastic bags under cooling and then transferred to laboratory for carrying out different operations. After the drying of all samples they were crushed and sieved through a $63 \mu \mathrm{m}$ screento obtain homogeneous particles (20). Various acids and different conditions were used for executing digestion operation for all the sediment samples. In this study the same procedure previously described is used for the digestion of samples $(8,18,24)$.

\section{Results and Discussion:}

Four toxic elements such as mercury, arsenic , cadmium and lead were measured and 
calculated of geo accumulation index of all the stations selected for marine sediment and Shatt Al Arab sediment (upstream and downstream) from various regions in southern of Iraq in Basra governorate. All the results of the measurements are shown in Table 2.

Table 2. Concentration of total mercury, arsenic, cadmium and lead of stations selected from surface sediment samples

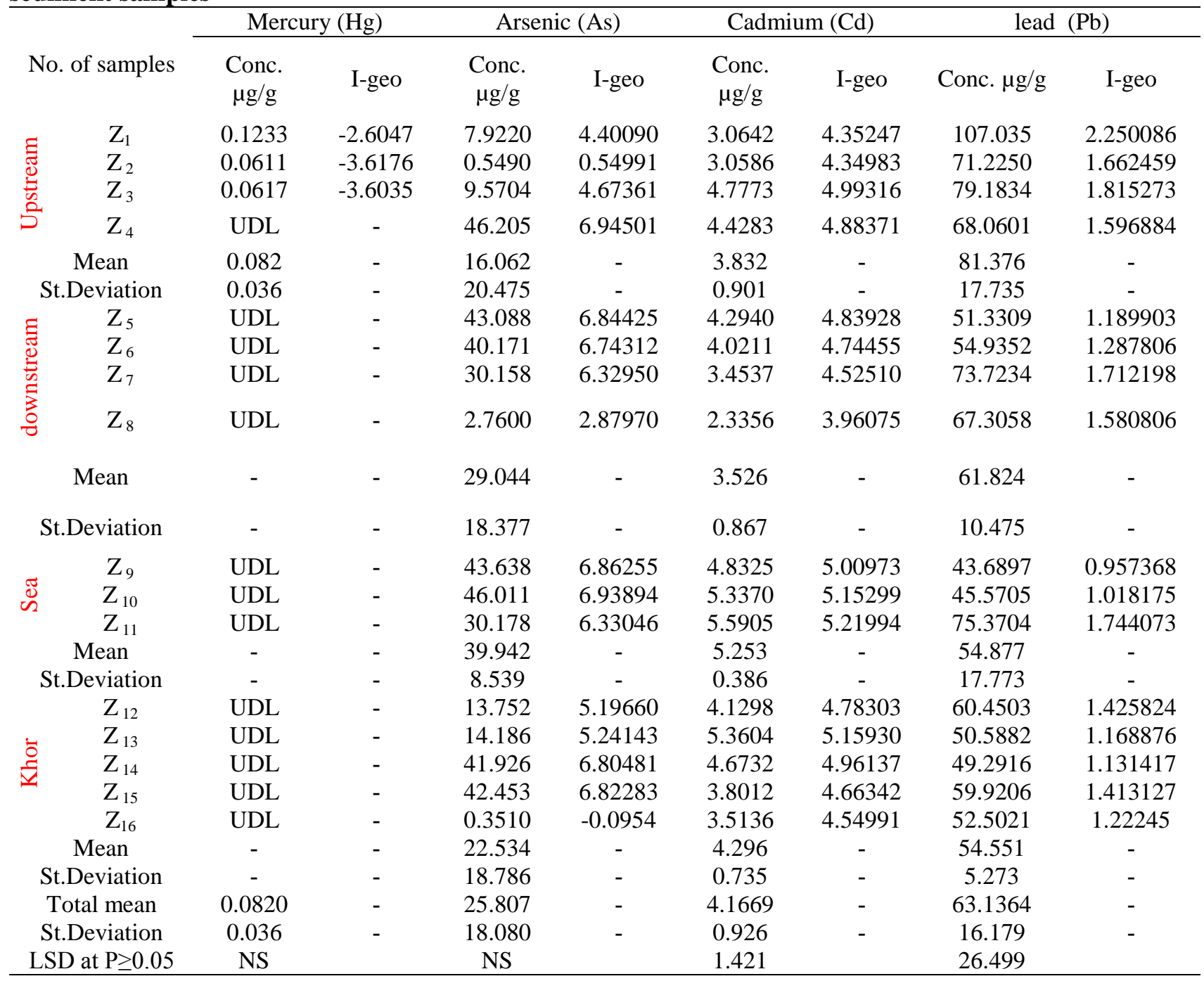

UDLUnder the Detection Limit

NS Not Significant

Mercury metal was measured by using ICP instrument. It is noted through the results of measurements of mercury for all the stations that the highest value of concentration of mercury was recorded in upstream area about $(0.1233 \pm 0.036$ $\mu \mathrm{g} / \mathrm{g}$ ) in station $Z_{1}$ compared with all sites and then the concentration of mercury was decreased towards station $Z_{3}$, because station $Z_{1}$ undergoes population activities and river navigation while stations $Z_{2}$ and $\mathrm{Z}_{3}$, undergo agricultural activities and also contains many industrial factories which have not undergone

dredging operations. The results of mercury analyses in this study recorded the lowest values when compared with the recorded data in previous studies for other regions in the Iraqi environment (25). While the remaining of the stations in all regions has not recorded any data and may be attributed to many reasons such as the type and components of the sediment in these regions and furthermore, the concentration increase of mercury depended the amount of mercury released into the environment without treatment. Several sources

may release mercury into the aquatic system as natural sources and anthropogenic sources such as components of soils, mercury-rich geological zones, movement of wind, weathering of rocks, combustion of fossil fuels, urban effluents, agricultural materials, mining and industrial effluents $(5,10,18,25)$. The geo accumulation index (I-geo)was calculated and it showed the all stations are within the class1 according to Muller 
classification .The results of mercury measurements are shown in Table 2 and Fig. 2,6 .

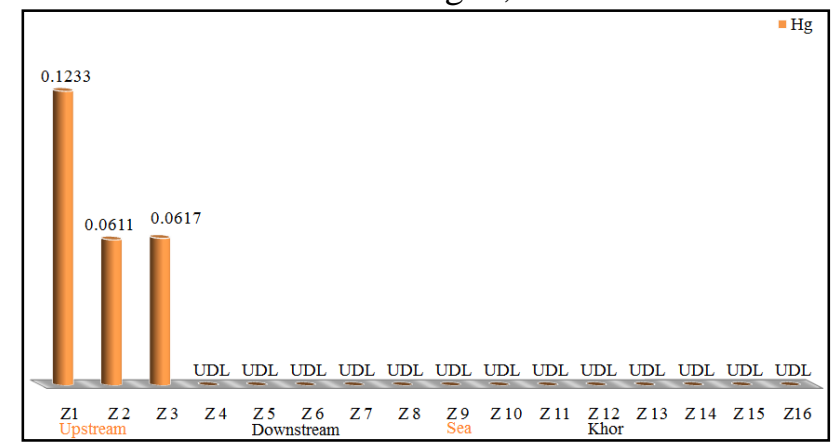

Figure 2. Concentration of total Mercury $\mu \mathrm{g} / \mathrm{g}$

Arsenic in the sixteen samples of sediment were measured by ICP technique. The arsenic existed in sediment being derived from oxidation operations for sulfide minerals such as pyrite, arsenian pyrite, arsenopyrite. The arsenic is found on the outer surfaces of some metals through adsorption operation especially with ferric oxide and depend on various conditions such as $\mathrm{pH}$, redox condition and specific surface area of minerals (26). The highest value of arsenic concentration for all chosen stations was recorded at station $\mathrm{Z}_{4}$ because this station undergoes many activities as industry, agriculture, navigation river, release urban effluents and pursuit of fishing by using some material containing arsenic. The concentrations of arsenic in Shatt Al-Arab river sites were compared, noted from these data the highest and lowest value was recorded in upstream region at station $Z_{4}, Z_{2}$ respectively and then there was an increase value of concentration of arsenic from station $\mathrm{Z}_{2}$ towards station $\mathrm{Z}_{4}$, downstream stations were recorded the lowest values of Arsenic concentration with compared of upstream and the values were gradually decreased from station $Z_{4}$ towards station $Z_{8}$ which might be due to the gradual decrease of fishing and the release of the urban effluents to river environment without treatment. In order to compare the results of Arsenic concentration between the marine sediment sites under study, the highest value was recorded in sea region at station $Z_{10}$ while recording the lowest value in Khor region at station $Z_{16}$, also noted the increase of Arsenic concentration value from Fao station towards site $Z_{10}$, after that the concentration of arsenic tend to decrease from sea region at station $\mathrm{Z}_{10}$ towards Khor region at station $\mathrm{Z}_{12}$ because this region is considered an important navigation road and also it's nearby Um qaser port therefore this area undergoes continuous dredging operations (27). Also noted of gradually increase once again in the concentration of arsenic the beginning in Khor region from station $Z_{13}$ towards Station $Z_{15}$ might be due to the impact of the loading and unloading operations of commercial loads and oil loads inside the Khor Al-Zubair port. Additionally the concentration of arsenic depends on the type and nature of sediment whether sand or clay or silt sediment(7), while station $\mathrm{Z}_{16}$ in Khor region recorded the lowest concentration $0.3510 \pm 18.786$ $\mu \mathrm{g} / \mathrm{g}$ of arsenic because these regions have not undergone any anthropogenic activities as industry, agriculture,mining or marine navigation. The concentration of arsenic for marine sediment in other studies recorded at range 0.58-121 $\mu \mathrm{g} / \mathrm{g}$ (5). The geo accumulation index (I-geo) was calculated for all stations and it showed the differences of classification among them. The stations of upstream region were calculated of $\mathrm{I}$-geo and record the station $Z_{4}$ is within class 6 while the stations $Z_{1}$ and $Z_{3}$ are within class 5 and class 2 for station $Z_{2}$, also I-geo is calculted for downstream region and showed the stations $Z_{5}-Z_{7}$ are within class 6 while the class 3 was calculated for station $Z_{8}$ and all stations for sea and Khor region were showed the Igeo data within class 6 except the station $\mathrm{Z}_{16}$ within class 1 .

The statistical analysis for all stations was studied and showed there are no significant differences in concentrations between zones at $\mathrm{P} \geq 0.05$ level (Table 2 and Fig. 3,6). Generally many of sources as natural and anthropogenic sources lead to receive the pollutant of arsenic to the environment such as rocks erosion, movement of wind, irrigation and drainage operations, wastewater, industrial waste, mining, uses of fossil fuels, pulp and paper production, cement manufacturing. All these processes cause the ecosystem pollution of arsenic $(6,7,18)$.

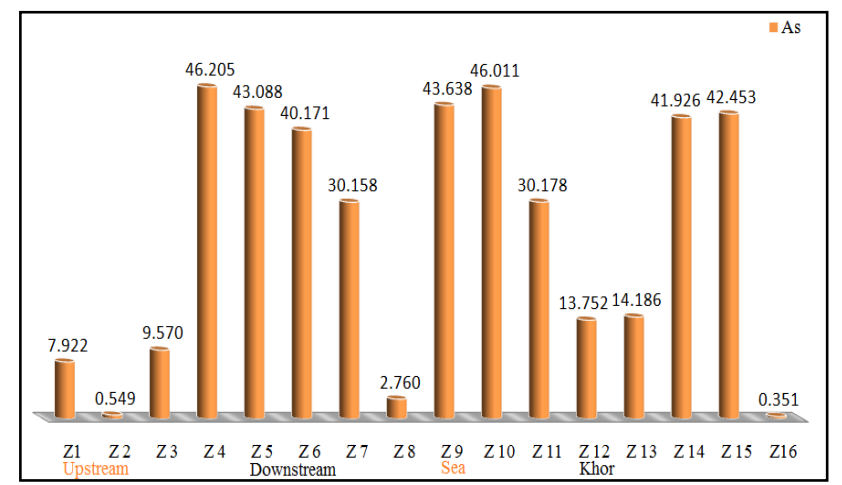

Figure 3. Concentration of total Arsenic $\mu \mathrm{g} / \mathrm{g}$

The atomic absorption spectroscopy was used for the determination of total concentration of lead and cadmium for all the samples of sediment. Lead has one state of oxidation (+II) and it's considered as toxic elements which causes several risks to human, animals and plants. Lead entered into the environment through many sources such as combustion of leaded fuel, movement of wind, 
untreated industrial effluents, automobile effluents, domestic waste, weathering of rocks and mining $(13,19)$. The results of lead measurements are shown in Table 2 and Fig.4, 6. This data recorded the highest value $(107.035 \pm 17.735 \mu \mathrm{g} / \mathrm{g})$ in upstream region at station $\mathrm{Z}_{1}$ when compared with all measurements of lead in different zones because this region has not undergone dredging operations moreover it undergone for several anthropogenic activities such as navigation river, released urban effluents to river without treatment, agriculture activities and additionally to natural sources and also to nature,type of components of sediment. The lead measurements for all sites on Shatt Al-Arab (upstream and downstream) were compared, highest value was recorded in upstream region at station $Z_{1}$, while the lowest value was recorded in downstream at station $Z_{5}$, after that the concentration of lead decreased in station $Z_{1}$ which might be attributed to a decrease in population growth which may lead to a decrease of combustion of leaded fuel and release to urban effluents. Also an increase was noted once again in the concentration value in site $Z_{3}$ because this region contains the generating station for electrical energy and also increase of agriculture activities and release as directly of wastewater and industrial waste to river without treatment. The concentration of lead recorded a decrease from site $\mathrm{Z}_{3}$ in upstream region towards site $\mathrm{Z}_{5}$ in downstream region and then gradually increased from site $Z_{5}$ towards site $Z_{7}$ because this station has undergone many activities such as river navigation and agricultural activities additionally it contains petroleum refinery (28), and then the decrease was slightly noted in downstream region of lead concentration in station $\mathrm{Z}_{8}$. The highest value $(75.3704 \pm 17.773 \mu \mathrm{g} / \mathrm{g})$ was recorded at station $Z_{11}$ in sea region when compared with all the marine stations (sea and Khor regions), while station $\mathrm{Z}_{9}$ in sea region recorded the lowest value of it, also it's noted that stations $Z_{12}$ and $Z_{15}$ in Khor region have recorded the highest values when compared with all the marine stations except station $\mathrm{Z}_{11}$ because these stations are considered as important regions for containing Um qaser and Khor Al-Zubair ports and thus leads to an increase of contamination in lead . Also station $\mathrm{Z}_{16}$ in Khor region recorded the highest value $(52.5021 \pm 5.273 \mu \mathrm{g} / \mathrm{g})$ because this area is a confluence zone between Basra canal and Khor AlZubair, Shatt al-Basra canal is a drainage channel, where wastewater and industrial waste are released without treatment (27).The data of lead concentration in the sediment samples were compared with those of the other studies for the Iraqi environment. The results of lead analyses recorded the lowest values when compared with the recorded data in the previous studies $(2,11)$, while it is consistent with the data recorded in other studies $(4,29)$. The I-geo data were calculated for all stations in different regions and showed that all stations are within class 2 except $Z_{1}$ station in upstream region within class 3 according to Muller classification(23) .

The statistical analysis for all stations shows there is no significant decline in the mean of lead concentration from upstream $(81.376 \pm 17.735$ $\mu \mathrm{g} / \mathrm{g})$ to downstream $(61.824 \pm 10.475 \mu \mathrm{g} / \mathrm{g})$. But there is a significant decline between the mean concentration of lead in upstream region and the mean concentration in sea region $(54.877 \pm 17.773$ $\mu \mathrm{g} / \mathrm{g})$ and the Khor region $(54.551 \pm 5.273 \mu \mathrm{g} / \mathrm{g})$.

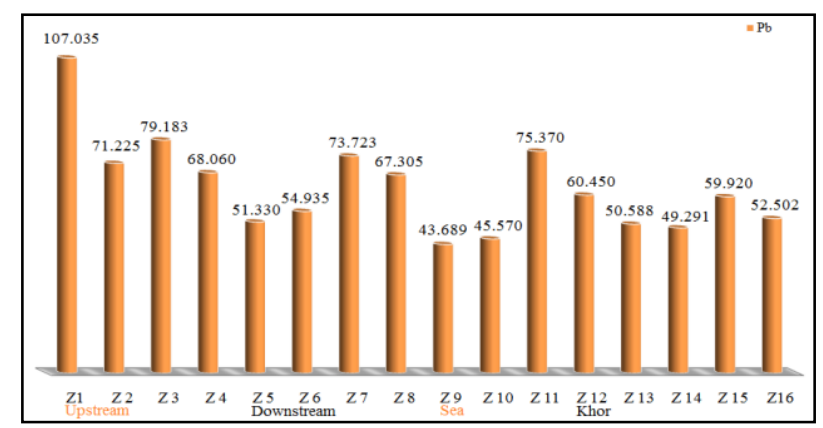

Figure 4. Concentration of total Lead $\mu \mathrm{g} / \mathrm{g}$

Cadmium is considered as a non-essential heavy metal and it has toxic properties moreover some cadmium compounds from different sources can be relatively soluble in water that leads to increase $\mathrm{Cd}$ concentration and furthermore it has ability of accumulation in fish tissue and thus it transfer to human through food chain. The kidney is considered critical target organ for toxicity of cadmium in humans. Cadmium in soil and sediment tend to be adsorbed on the surfaces of clay minerals, carbonates or hydrous oxides of iron and manganese and depended on $\mathrm{pH}$ conditions of soil and sediment (17). The highest value (5.5905 \pm 0.386 $\mu \mathrm{g} / \mathrm{g}$ ) of cadmium concentration was recorded in station $\mathrm{Z}_{11}$ in Sea region when compared with all the other zones measurements, while the lowest value $(2.3356 \pm 0.867 \mu \mathrm{g} / \mathrm{g})$ was recorded in station $\mathrm{Z}_{8}$ in downstream region. The results of cadmium measurement were compared in all the stations of Shatt Al-Arab river (upstream and downstream), the concentration of cadmium is recorded in station $Z_{1}$ and $Z_{2}$ in upstream region almost is equal and then also noted an increase in the concentration values of cadmium at station $Z_{3}$, while gradual decrease of concentration of cadmium was also noted from site $\mathrm{Z}_{3}$ in upstream region towards site $\mathrm{Z}_{8}$ in downstream region which might be due to many reasons such as a decrease of urban regions thus leads to decrease of release of domestic waste water to river without treatment, also leads to decrease in the combustion of fossil fuel and waste 
incineration. The concentration of cadmium for all the marine sites $Z_{9}-Z_{16}$ in sea and Khor regions was compared and the highest value was recorded at station $\mathrm{Z}_{11}$ in sea region, while the station $\mathrm{Z}_{16}$ in Khor region recorded the lowest value (3.5136 \pm $0.735 \mu \mathrm{g} / \mathrm{g}$ ). As well as the increase of cadmium concentration was noted from station $Z_{8}$ in downstream region towards station $Z_{11}$ in sea region because these regions are important areas and represent the marine navigation road between Iraq and Kuwait and especially site $Z_{11}$ (27), while a decrease of cadmium concentration was noted at station $Z_{12}$ in Khor region and once again the concentration of cadmium is increased at station $\mathrm{Z}_{13}$. After that a gradual decrease of cadmium concentration was recorded from Station $Z_{13}$ towards station $\mathrm{Z}_{16}$. Station $\mathrm{Z}_{12}$ and $\mathrm{Z}_{15}$ in Khor region are important regions representing commercial and oil ports which undergoes the loading and unloading operations of commercial loads and oil loads inside the Khor Al-Zubair port and Um qaser port, while station $\mathrm{Z}_{16}$ in Khor region recorded a low concentration $(3.5136 \pm 0.735 \mu \mathrm{g} / \mathrm{g})$ when compared with Sea and Khor region, but it's recorded the highest value when compared with the other stations such as $Z_{1}, Z_{2}, Z_{7}$ and $Z_{8}$ in upstream and downstream region because this region represents the confluence zone between the Shatt alBasra canal and Khor Al-Zubair port. Shatt al-Basra canal is considered as a drainage channel, where the domestic waste water and industrial waste are released without treatment $(3,27)$. The results of cadmium analyses have recorded the lowest values when compared with the recorded data in previous studies in the Iraqi environment $(2,11)$, while it is consistent with the data recorded in other studies $(4,30)$. The geo accumulation index was calculated for all stations and it showed all stations for upstream and downstream for Shatt Al-Arab river are within class 5 except the station $\mathrm{Z}_{8}$ within class 4 , the marine regions ( sea and Khor) showed class 6 for all station in sea region while the Khor region appeared according to Muller classification within class 5 excepted $Z_{13}$ station within class 6 .

The statistical analysis by the ANOVA shows there are no significant differences of decrease of the mean concentration from upstream region $(3.832 \pm 0.901 \mu \mathrm{g} / \mathrm{g})$ to downstream region $(3.526 \pm 0.867 \mu \mathrm{g} / \mathrm{g})$ While there is a significant increase of the mean concentration of sea region $(5.253 \pm 0.386 \mu \mathrm{g} / \mathrm{g})$ but not with the mean concentration of $\mathrm{Cd}$ in the Khor region (4.296 \pm $0.735 \mu \mathrm{g} / \mathrm{g}$ ). The major sources of cadmium pollution in the environment through the natural and anthropogenic sources such as erosion of rocks , movement of wind, rain water, agriculture activities, domestic waste water, combustion coal and oil,waste incineration and industrial waste $(4,18,31)$. The results of cadmium measurements are shown in Table 2 and Fig.5, 6.

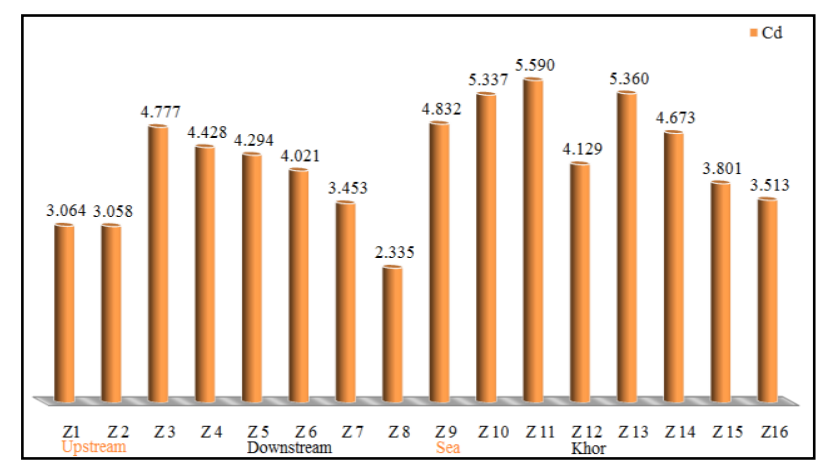

Figure 5. Concentration of total Cadmium $\mu \mathrm{g} / \mathrm{g}$

Heavy metals are present naturally in the environment, they exist in water, sediments, plants and animals furthermore can be released into the environment by many processes from nature and anthropogenic sources such as weathering of rock, mining, combustion of fossil fuel, urban effluents, untreated industrial effluents, movement of wind, rain water, waste incineration and irrigation and drainage operations $(4,18,19,25,27)$. All the results of heavy metals measurements in this study are showed in Table 2 and Fig.6.

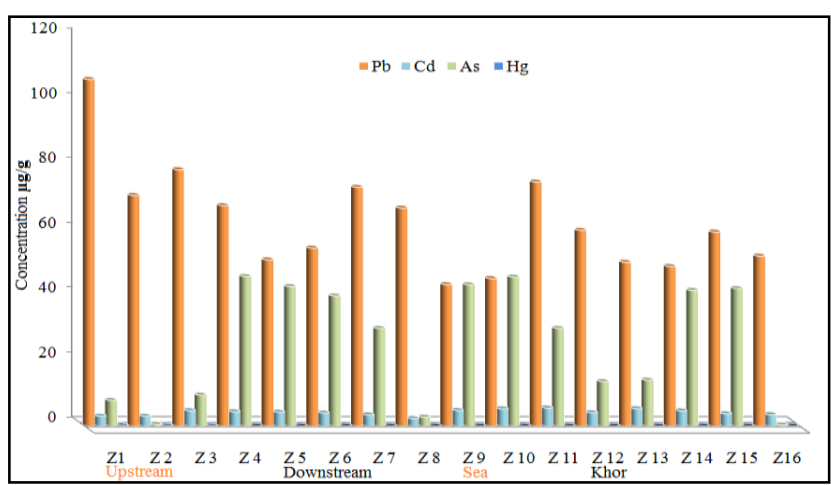

Figure 6. Concentration of elements $\mu \mathrm{g} / \mathrm{g}$

\section{Conflicts of Interest: None.}

\section{References:}

1. Kokali A, Sulçe S, Bici E, Poga Z, Hoxha A, Dungu E.Heavy Metals In Water and Sediments of Drini River and Kunevain Lagoons.J.Int. Acade. Res. Multidis. 2015 Sep; 3(8) :1-10 .

2. Al-khuzaie DKK.Assessment of Sediment Quality Collected From Shatt Al-Arab River, Basra, Southern Iraq.J.Int. Acade. RES. Multidis.2015july; 3(6): 235246.

3. Abdulnabi Z A , Hassan W F, Al-khuzaie DKK, Saleh S M, Hashim M G .Evaluation of Selenium Levels For The Water Surfaces in Southern of Iraq.J.Chem. Pharm. Res. 2015; 7(10) : 495-501.

4. Salman J M, Hassan F M, Abdulameer S H . A Study on The Fate of Some Heavy Metals in Water and 
Sediments in Lotic Ecosystems .Int. J.Chem. Phy. Sci.2015 Mar-Apr; 4(2) :36-45.

5. UNEP. Arsenic, mercury and Selenium in The Marine Environment.UNEP Regional Seas Reports and Studies No. 92 . GESA MP Reports and Studies No. 28. 1988.

6. Sindhu P, Sharma Dr. A, Rai D, Priya . Toxicity of Arsenic on Growth Parameters of Wheat (TriticumAestivumL.) .J.Int. Acade. Res. Multidis . 2015 July ; 3(6) : 27-31 .

7. Panagiotaras D, Panagopoulos G, Papoulis D, Avramidis P. Geochemistry - Earth's System Processes. Arsenic Geochemistry in Groundwater System . 2012 May; Publisher InTech .

8. Morita M, Yoshinaga J, Edmonds J S. The Determination of Mercury Species in Environmental and Biological Samples (Technical Report). Int.U.PureAppl.Chem. 1998; 70(8) : 1585-1615 .

9. Ahmed M J,Alam M S . A Rapid Spectrophotometric Method For The Determination of Mercury in Environmental, Biological, Soil and Plant Samples Using Diphenylthiocarbazone . Spectroscopy .2003; 17: 45-52.

10. Squadrone S, Benedetto A, Brizio P, PrearoM ,Abete M C. Mercury And Selenium In European Catfish (SilurusGlanis) From Northern Italian Rivers: Can Molar Ratio Be A Predictive Factor For Mercury Toxicity In A Top Predator?.Chemosphere .2015; 119 : 24-30

11. Hassan W F, Albadran BN, Faraj MA. The geochemical distribution of trace metals in shatt alarab river sediments. Mar. Meso. 2008; 23(2): 419436 .

12. Abdulnabi ZA. Assessment of some toxic elements levels in Iraqi marine water. Mesopot. J. Mar. Sci.2016; 31(1): 85 - 94.

13. Stamatis N, Kamidis N, Sylaios G. Sediment and Suspended Matter Lead Contamination in The Gulf Of Kavala, Greece. Env. Mon. Asse. 2006; 115: 433449.

14. Benzer S, Arslan H, Uzel N, Gül A,Yılmaz M. Concentrations of metals in water, sediment and tissues of CyprinuscarpioL., 1758 from Mogan Lake (Turkey) . Ir. J. Fish. Sci. 2013; 12(1) : 45-55 .

15. Krebs R E. The History and use of our earth's chemical elements. 2nd ed. London: Greenwood Press; 2006 . p.143-146.

16. Linde M. Trace Metals in Urban Soils- Stockholm as a Case Study. PhD.Thesis.Uppsala: Swedish University of Agricultural Sciences; 2005.

17. UNEP. Fnal review of scientific information on cadmium. 2010. December.

18. Sylaios G, KamidisN , Stamatis N .Assessment of Trace Metals Contamination in the Suspended Matter and Sediments of a Semi-enclosed Mediterranean Gulf . Soil and Sedi. Conta. 2012; 21: 673-700 .

19. Al-Imarah FJM, Al-Saad HT, Al-Hillo A A , AlMudhafar NA ,Saleh SM . ICP detection of chemical elements in the sediments along Shatt Al Arab Estuary and Khor Abdullah/Southern Iraq. Int.J.Env. \&Water .2015; 4(4) : 11-18.

20. Al-SaadHt , Al-ImarahFjm , Saeed Mar . Distribution And Levels of Trace Metals in The Red Sea Coasts and Comparison with Their Levels in The Arabian Gulf . Marina Meso. 2007; 22 (1) :1-16.

21. Müller G. Index of geo accumulation in sediments of the Rhine River. Geo. J. 1969; 2(3): 108-118 .

22. Kabata-Pendias A. Trace elements in soils and plants. 4th ed. CRC Press.2011.543p.

23. Ong MC, Menier D, Shazili NAM, Kamaruzzaman BY . Geochemical Characteristics of Heavy Metals Concentration in Sediments of Quiberon Bay Waters, South Brittany, France .Orient. J. Chem. 2013; 29(1): 39-45.

24. Sparks DL, Page AI, Helmke DA, Loeppert RH, Soltanpour PN, Tabatabai MA, Johnston CT, Sumuer ME. Method of soil analysis Part. 3. Chemical methods. Madison Wisconsin, U.S.A. 1996.

25. Salman JM, Hussein AH, Hussein F H .Investigating Mercury Existence in Euphrates River in Iraq. Asian J.Cur. Chem. 2011; 1(3): 28-38.

26. Peters SC, Burkert L. The occurrence and geochemistry of arsenic in groundwaters of the Newark basin of Pennsylvania. App. Geochem. 2008; $23: 85-98$.

27. Abdulnabi Z A, Al-khuzaie DKK, Jarallah HM, Hassan W F , Saleh S M . Evaluation of Selenium and Iron Levels in Shatt Al-Arab Sediment and the Iraqi Marine Environment. Ind. J. Natu.1 Sci. 2016; 6(34) : 10475- 10482 .

28. Mahdi BA. Environmental Pollution In Shatt Al-Arab Estuary. J.Int. Acade. RES. Multidis. 2015; 3(6) : 3242 .

29. Al-Hejuje M M, Al-Saad H T, Hussain NA . Application of geo-accumulation index (I-geo) for assessment the sediments contamination with heavy metals at Shatt Al-Arab River-Iraq. J.Sci.Eng.Res. $2018 ; 5(2): 342-351$.

30. Al-Khafaji B Y, Al-Awady AA, Farhood AT. Distribution of Some Trace Metals in Al-Chibayish Marsh of Part Ecosystem in Thi-Qar Province in Southern Iraq .World J.Pharm.Res.2015 ; 4(8) : 14431456.

31. ATSDR (Agency for Toxic Substances and Disease Registry). 2008. Cadmium .7440-43-9 .Federal Recycling Program. 


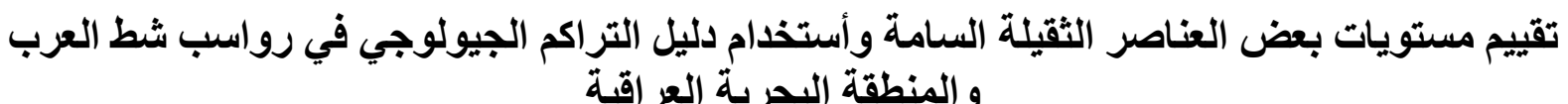

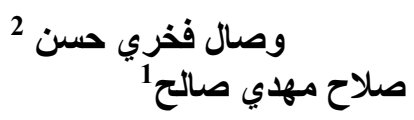

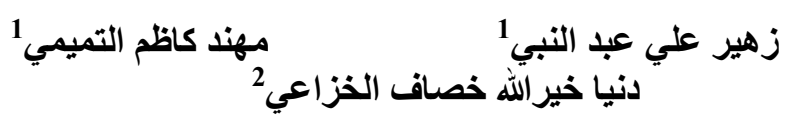

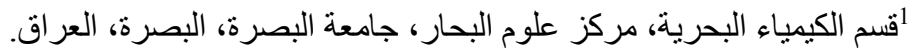

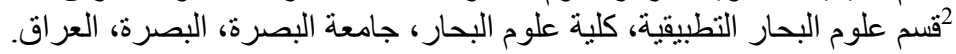

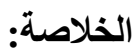

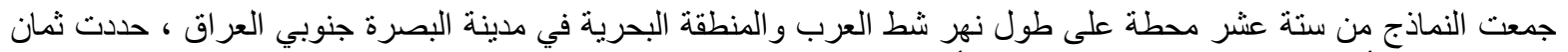

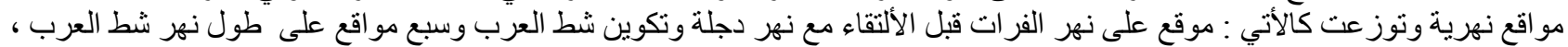

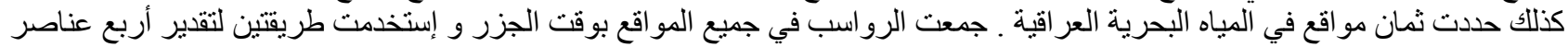

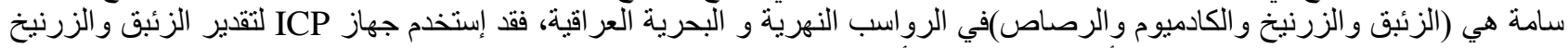

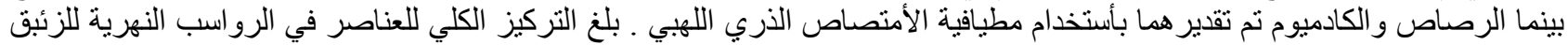

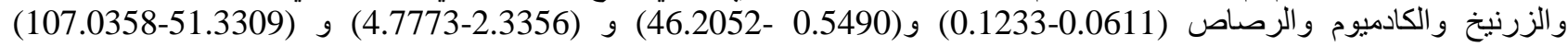

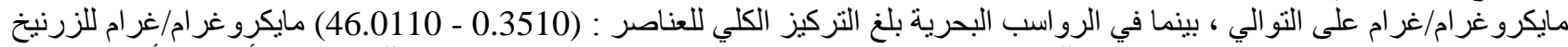

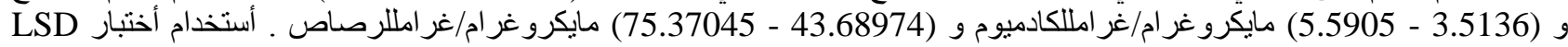
لجميع النتائج وبمستوى الجيولوجي لجميع العناصر في المحطات المختلفة . لجن.

الكلمات المفتاحية : مطيافية الأمتصاص الذري ، تقنية ICP ، دليل التر اكم الجيولوجي I-geo 